\title{
Nutritional and Sensory Evaluation of Novel Ice Cream Products Formulated From Kunu-Zaki Fortified with Fruit Pulp
}

\author{
Ogo Ogo ${ }^{1,2 *}$, Bai Emmanuella², Efiong Esienanwan33, Enenche Daniel2 \\ ${ }^{1}$ Department of Biochemistry, College of Health Sciences, Benue State University, Makurdi, Benue State, Nigeria \\ ${ }^{2}$ Center for Food Technology and Research, Benue State University, Makurdi, Benue State, Nigeria \\ ${ }^{3}$ Department of Biochemistry, Faculty of Science, Federal University, Lafia, Nasarawa State, Nigeria \\ Email: *oogo@bsum.edu.ng
}

How to cite this paper: Ogo, O., Emmanuella, B., Esienanwan, E. and Daniel, E. (2021) Nutritional and Sensory Evaluation of Novel Ice Cream Products Formulated From Kunu-Zaki Fortified with Fruit Pulp. Food and Nutrition Sciences, 12, 439-451. https://doi.org/10.4236/fns.2021.125034

Received: February 14, 2021

Accepted: May 23, 2021

Published: May 26, 2021

Copyright $\odot 2021$ by author(s) and Scientific Research Publishing Inc. This work is licensed under the Creative Commons Attribution International License (CC BY 4.0).

http://creativecommons.org/licenses/by/4.0/

\begin{abstract}
Consumption of ice cream produced from dairy products has been reportedly associated with health hazards. To circumvent this, this study was undertaken to formulate plant-based ice cream using kunu-zaki and soymilk (as substitutes for dairy milk) fortified with mango, banana and avocado. Standard method for the preparation of ice cream was modified to formulate three variants of kunu-zaki ice cream designated as B (40\% kunu-zaki, $40 \%$ banana pulp and $20 \%$ soymilk); C (40\% kunu-zaki, $40 \%$ mango pulp and $20 \%$ soymilk); D (40\% kunu-zaki, $40 \%$ avocado pulp and $20 \%$ soymilk), while control sample A was commercial dairy-based ice cream. Analyses of proximate, mineral and vitamin compositions were carried out on the samples following standard procedures. The results showed lower fat content in all the formulated ice cream samples, which ranged from $0.60-0.96 \mathrm{~g} / 100 \mathrm{~g}$ compared to the control sample with fat content of $8.15 \mathrm{~g} / 100 \mathrm{~g}$. Similarly, the formulated ice cream samples have significant protein content with sample D recording the highest value of $3.67 \mathrm{~g} / 100 \mathrm{~g}$ compared to control sample. Samples B and C contained higher vitamin $\mathrm{C}$, vitamin $\mathrm{B}_{6}$, calcium and sodium content in comparison to sample A. Sensory evaluation showed that samples B and sample $C$ were the most acceptable ice cream variants in comparison to the control sample. These findings lend credence to the strategy of value addition for providing healthier food alternatives while contributing to the reduction in post-harvest losses of fruits utilized as fortificants.
\end{abstract}

\section{Keywords}

Kunu-Zaki, Ice Cream, Value Addition, Soymilk, Nutritional Value, 
Fruit Pulp

\section{Introduction}

Ice cream is a frozen dessert that is prepared mainly from dairy products such as milk and cream. The type as well as the ingredients used in the production of ice cream determines its nutrient component [1]. In many countries, including Nigeria, cow milk is predominantly used in the production of ice cream in addition to fats from buffalo and other animals. However, a reasonable number of reports in the literature have documented growing health concerns associated with consumption of conventional dairy ice cream, which include lactose intolerance, hypercholesterolemia among others [2]. In addition, there are also high economic costs associated with the use of dairy milk, which is mostly imported making the product unaffordable to many low-income earners. Furthermore, ice creams have been recommended for patients at risk of malnutrition to enable them to consume extra energy and fluids, however, the nutritional quality of commonly available ice creams is largely compromised owing to overdependence on dairy products as starting ingredients. Consequently, attempts to obtain and utilize cheaper substitutes with no chemical additives and comparative or even higher nutritional quality, particularly, in terms of improved protein, vitamin, and mineral contents have been canvassed [3]. Thus the replacement of dairy base with cheaper options and the practice of value addition with other fruits can serve a dual purpose of addressing malnutrition currently plaguing the sub-Saharan population as well as contributing to control of post-harvest losses of such plant harvests [4].

Kunu-zaki is a sweetened cereal-based non-alcoholic beverage drink [5], which traditionally originates from Northern Nigeria where sorghum, millet or maize could be used for preparation depending on seasonal availability [6]. As widely accepted and enjoyable as kunu-zaki is among the Northerners and others who consume the drink, its nutritional quality is compromised owing to nutrient losses during the various stages of production such as steeping, milling and sieving [7]. However, its nutritional value can be boosted with addition of soybean (Glycine $\max L$.), which has been previously shown to be loaded with essential amino acids [8], exogenously required to improve one's nutritional status. The formulation of ice cream from cereal-based kunu-zaki supplemented with soybean milk and fortified with banana, mango and avocado fruits as vehicles for delivering a variety of vitamins and minerals [9], can contribute to addressing malnutrition, whose incidence is on the increase particularly in developing societies such as Nigeria [10] [11]. The need for plant-based ice creams becomes even more important and apt even as some researchers have called for reduction in the amount of milk used in production to reduce environmental impact as well as improve health-driven market trends [12]. This study, therefore, evaluates a plant-based ice cream product fortified with fruits with the aim of improving its nutritional 
value while also contributing to post-harvest management of fruits through value addition.

\section{Material and Methods}

\subsection{Study Area}

The study was carried out at the Food Laboratory, Center for Food Research and Technology, Benue State University, Makurdi, between June 2018 and September 2019.

\subsection{Sample Collection}

Sorghum, millet and soybean seeds and other ingredients for the preparation of kunu-zaki were purchased from Modern market, while banana, mango and avocado fruits were bought from Railway fruit market, all in Makurdi metropolis of Benue State, Nigeria.

\subsection{Preparation of "Kunu-Zaki"}

Sorghum grains $(2 \mathrm{~kg})$ and millet $(2 \mathrm{~kg})$ were weighed and sorted by hand to remove foreign substances and dirts. They were then washed separately under running water to ensure it was clean before being steeped in water for $12 \mathrm{~h}$ and drained. Ginger was also washed along with the other ingredients and then ground into paste separately from the grains using a wet milling machine (disc attrition). To the paste, $4 \mathrm{~L}$ of boiling water was added to the large portion containing the composite paste to gelatinize the starch. The smaller portion containing the ingredients was then added to the larger portion immediately and stirred to mix properly and left overnight for saccharification/liquefaction according to previous method [13]. The mixture was sieved the next day using a muslin cloth and kept under hygienic condition for further use.

\subsection{Preparation of Soybean Milk}

Sand and solid impurities were hand-picked before washing the soybean seeds. The seeds were then soaked in water for $12 \mathrm{~h}$ and the husks were removed by rubbing with hands. It was then drained out and blended using a wet milling machine (disc attrition). The slurry was then filtered using a double layered muslin cloth. Ginger was added and boiled for about $10 \mathrm{~min}$ while stirring constantly according to boiling extraction technique we previously used.

\subsection{Preparation of Ice Cream Variants}

Different ice cream samples were prepared by modifying the method of standardized ice cream preparation [14] with modifications. Kunu-zaki ice cream variants were prepared by a combination of kunu-zaki and soymilk as base with banana, mango and avocado as fortificants. The fruits were first washed and frozen in an airtight Ziploc bag for $8 \mathrm{~h}$ before been used to process kunu-zaki with soymilk blends in the selected ratios determined from preliminary trials as indi- 
cated in the sample labelled A - D in Figure 1 below.

Sample A was a commercial ice cream made from diary base as control. Sample B, C and D were formulated from $40 \%$ kunu-zaki, $20 \%$ soymilk and $40 \%$ banana (B); $40 \%$ mango (C) and 40\% avocado (D) respectively.

\subsection{Determination of Proximate Composition}

The proximate analysis of samples were carried out according to approved procedures [15]. Moisture content was determined in a hot-air circulating oven (Gallenkamp, UK). For total ash content, samples of known weights were incinerated at $550^{\circ} \mathrm{C}$ in a muffle furnace (Gallenkamp, UK). Crude fat determination was done by completely extracting a known weight sample in petroleum ether while protein content was determined using the micro Kjeldahl method [16]. Carbohydrate content was measured by difference approach.

\subsection{Determination of Physicochemical Properties}

The $\mathrm{pH}$ was determined directly using a digital $\mathrm{pH}$ meter (Jenway, England). Total titrable acidity and total solid contents were determined according to approved methods.

\subsection{Determination of Amino Acid Profile}

The Amino acid profile of the ice cream samples was determined according to methods described by Benitez, using an Applied Biosystems PTH Amino Acid Analyzer (MODEL: 120 A). Tryptophan was determined separately due to its susceptibility to acid hydrolysis by using thioglycolic acid with $6 \mathrm{~N}$ hydrochloric acid to preserve it according to standard method [17] [18].

\subsection{Sensory Evaluation}

Sensory evaluation of the four ice cream samples was conducted by a 10 -member trained panelists. The descriptive 9-point Hedonic scale with 9-like extremely to 1-dislike extremely as described by [19], was used for the evaluation. Ice cream

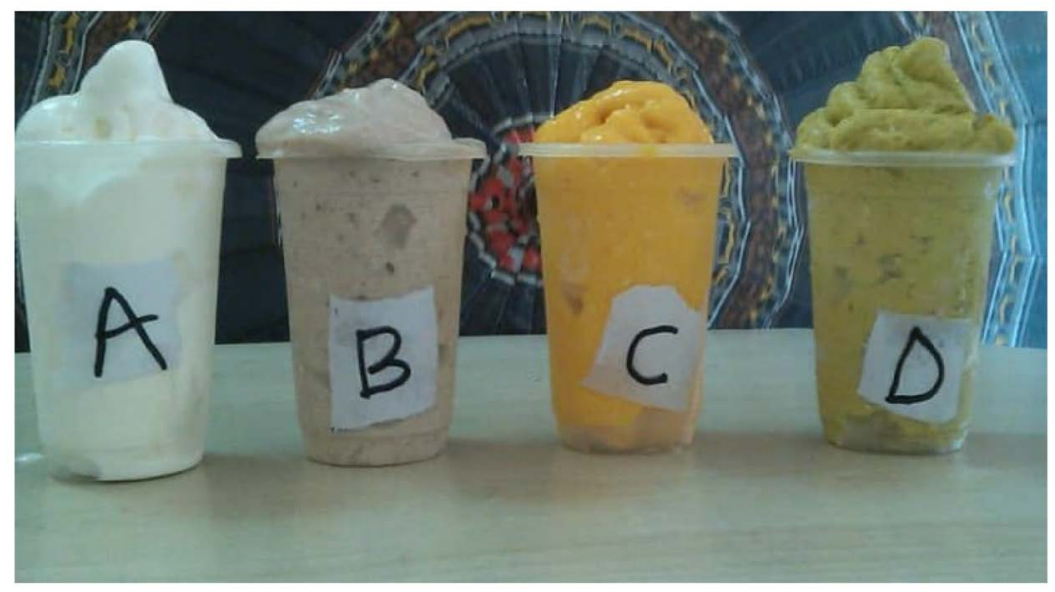

Figure 1. Formulated ice cream variants and control sample. 
quality was judged in terms of appearance/colour, taste, flavour, mouth feel (texture) and overall acceptability.

\subsection{Statistical Analysis}

Measurements of each parameter were carried out in duplicates for all determinations. Data were analysed using Statistical Package for the Social Sciences (SPSS version 16.0). Similarities and differences amongst data sets were subjected to analysis of variance (ANOVA) with the New Duncan Multiple Range Test (NDMRT) employed to separate the means expressed as mean \pm standard deviation at $95 \%$ confidence level $(\mathrm{p}<0.05)$.

\section{Results and Discussion}

\subsection{Proximate Composition}

The results of proximate composition are presented in Table 1 . The moisture content of the value-added ice creams (B - D) varied from $72.01 \%$ to $78.08 \%$ comparable to the commercial sample, which recorded $63.73 \%$. The slight difference in values of experimental samples and the control may be due the presence of fruits, which naturally contain significant amount of water. However, the result of moisture contents is similar to those reported for formulated ice creams fortified with guava pulp as well as calcium and vitamin D [20]. Ash content which is an indication of the mineral content was not significantly different from sample A which did not agree with the findings of [21]. The higher value observed in the control may be as a result of inclusion chemical compounds as additives in commercial ice cream products. The observed low percentage ash in the formulated ice cream samples may be attributed to the processing techniques for both kunu-zaki and soymilk [22], which might have resulted in some micronutrients leaching out through the sieved water. The fat content in all the formulated ice cream samples, which varied from $0.6 \%$ to $0.9 \%$ are significantly lower than the control sample recording above $8 \%$. This could be attributed to the low fat content of kunu-zaki and the fruits as noted by other researchers [23]. The fat contents are consistent with the recommendation of consumption of food items with low fat composition for healthier nutrition. However, the high fat content of the

Table 1. Proximate composition of the ice cream samples.

\begin{tabular}{ccccccc}
\hline Sample & $\begin{array}{c}\text { Moisture } \\
(\%)\end{array}$ & $\begin{array}{c}\text { Fat } \\
(\%)\end{array}$ & $\begin{array}{c}\text { Protein } \\
(\%)\end{array}$ & $\begin{array}{c}\text { Ash } \\
(\%)\end{array}$ & $\begin{array}{c}\text { Carbohydrate } \\
(\%)\end{array}$ & Fibre \\
\hline A & $63.73 \pm 0.134^{\mathrm{a}}$ & $8.15 \pm 0.162^{\mathrm{c}}$ & $2.55 \pm 0.014^{\mathrm{b}}$ & $1.19 \pm 0.028^{\mathrm{c}}$ & $21.57 \pm 0.226^{\mathrm{c}}$ & $2.61 \pm 0.141^{\mathrm{bc}}$ \\
B & $72.01 \pm 0.056^{\mathrm{b}}$ & $0.60 \pm 0.014^{\mathrm{a}}$ & $2.19 \pm 0.056^{\mathrm{a}}$ & $0.01 \pm 0.003^{\mathrm{a}}$ & $23.42 \pm 0.190^{\mathrm{d}}$ & $1.77 \pm 0.282^{\mathrm{a}}$ \\
C & $75.27 \pm 0.353^{\mathrm{b}}$ & $0.85 \pm 0.028^{\mathrm{b}}$ & $2.16 \pm 0.014^{\mathrm{a}}$ & $1.01 \pm 0.127^{\mathrm{d}}$ & $17.65 \pm 0.353^{\mathrm{a}}$ & $2.95 \pm 0.042^{\mathrm{c}}$ \\
D & $78.08 \pm 0.424^{\mathrm{c}}$ & $0.96 \pm 0.036^{\mathrm{b}}$ & $3.36 \pm 0.063^{\mathrm{c}}$ & $0.56 \pm 0.070^{\mathrm{b}}$ & $15.79 \pm 0.395^{\mathrm{b}}$ & $2.17 \pm 0.197^{\mathrm{ab}}$ \\
ANOVA & 0.001 & 0.001 & 0.001 & 0.001 & 0.001 & 0.012 \\
\hline
\end{tabular}

Values are Mean \pm Standard deviation for two independent determinations. Values with different superscript down the column differ significantly at $\mathrm{p}<0.05$ (Duncan Multiple range test). 
commercial sample in this study agrees with the high saturated fat contained in other commercial samples previously analysed [24]. Crude protein contents of the samples range from 2.19 to $3.6 \mathrm{~g} / 100 \mathrm{~g}$. Although samples B and C contained lower amounts of protein compared to sample $A$, the values fall below standard range of $3.45 \mathrm{~g} / 100 \mathrm{~g}$ to $7.38 \mathrm{~g} / 100 \mathrm{~g}$ [25]. On the other hand, sample D has the highest protein content of $3.66 \mathrm{~g} / 100 \mathrm{~g}$ higher than the control sample. The higher protein content observed in sample $\mathrm{D}$ could be traced to inclusion of avocado pear, which was previously reported to contain between $1 \%$ - 3\% protein content in its pulp. Giving that protein-energy malnutrition is a public health concern, consumption of value-added ice cream may be helpful in supplementing protein nutriture. The carbohydrate content of the formulated ice cream samples ranged from $23.4 \%$ to $15.79 \%$ and was all significantly different $(\mathrm{p}<0.05)$. The carbohydrate content of the control sample was $21.57 \%$ which agreed with other findings [26], which observed that dairy ice cream is high in carbohydrates and sugar. The carbohydrate content of the formulated ice cream samples might have been impacted by the carbohydrate content of kunu-zaki beverage drink known for use to replace lost energy during activity. Crude fibre content of formulated ice cream sample $\mathrm{C}$ was higher than the control sample. This according to studies may be from the soluble dietary fibre contained in mango which contributes in lowering cholesterol levels [27]. The crude fibre content observed in sample A may be as a result of the emulsifiers and stabilizers used in production of commercial ice cream because standard dairy ice cream is understandably low in crude fibre. Overall, value addition of the novel products increased the proximate compositions in similar manner to that previously reported [28], who considered the effect of fortification of ice cream with nuts and seeds.

\subsection{Vitamin and Mineral Contents}

The results of vitamins and mineral composition of the ice cream samples are presented in Table 2. The result showed that the formulated ice cream compared with the control sample contained reasonable amounts of vitamin $\mathrm{C}$ ranging from 18 - $38 \mathrm{mg} / 100 \mathrm{~g}$. Sample $\mathrm{C}$ fortified with mango had the highest value which is consistent with established knowledge of high vitamin $\mathrm{C}$ content of this fruit,

Table 2. Vitamin and mineral content of the ice cream samples.

\begin{tabular}{ccccc}
\hline Sample & VIT B $_{6}(\mathrm{mg} / 100 \mathrm{~g})$ & VIT C $(\mathrm{mg} / 100 \mathrm{~g})_{\mathrm{Ca}(\mathrm{ppm})}$ & $\mathrm{Na}(\mathrm{ppm})$ \\
\hline A & $0.31 \pm 0.077^{\mathrm{c}}$ & $21.385 \pm 0.544^{\mathrm{c}}$ & $0.001 \pm 0.000^{\mathrm{a}}$ & $0.023 \pm 0.001^{\mathrm{b}}$ \\
B & $0.498 \pm 0.021^{\mathrm{b}}$ & $18.79 \pm 0.049^{\mathrm{b}}$ & $0.006 \pm 0.000^{\mathrm{c}}$ & $0.003 \pm 0.000^{\mathrm{a}}$ \\
C & $31.28 \pm 0.233^{\mathrm{d}}$ & $38.42 \pm 0.063^{\mathrm{d}}$ & $0.018 \pm 0.000^{\mathrm{d}}$ & $0.136 \pm 0.006^{\mathrm{c}}$ \\
D & $0.118 \pm 0.001^{\mathrm{a}}$ & $21.385 \pm 0.544^{\mathrm{c}}$ & $0.005 \pm 0.000^{\mathrm{b}}$ & $0.011 \pm 0.000^{\mathrm{a}}$ \\
p-value & 0.001 & 0.001 & 0.001 & 0.001 \\
\hline
\end{tabular}

Values are Mean \pm Standard deviation for two independent determinations. Values with different superscript down the column differ significantly at $\mathrm{p}<0.05$ (Duncan Multiple range test). 
and the findings of increased ascorbic acid found in ice cream samples fortified with Kiwi juice [29]. Consumption of food items with vitamin C as natural antioxidant is encouraged owing to its ability to neutralize reactive oxygen species, which if unchecked could potentiate the growth of cancerous cells [30]. This is further supported by the report that inclusion of synthetic ascorbic acid in food preparation may be deleterious in the sense that the artificial form can react with sodium benzoate to form benzene ring, which has been reported to be a potent carcinogen [31]. In similar vein, the vitamin B6 content of sample $\mathrm{C}$ was found to be significantly $(\mathrm{p}<0.05)$ higher than the control sample A consistent with previous finding [32]. Vitamin B6 plays an important role in protein and glucose metabolism as well as synthesis of hemoglobin, thus the formulated ice cream samples could hold promise for the supply of this essential nutrient. The calcium contents of our products were all significantly different $(p<0.05)$ from that in sample A. Although the value found here are lower than those reported for standard dairy milk [33], which may be due to the different brand of dairy product used. The values recorded for sodium are low; the amount contained in sample $\mathrm{C}$ is significantly higher than the control sample. The claim that frozen dessert products are potential carriers of functional health-benefitting ingredients and thus can be useful for both dietetic and therapeutic purposes [34] [35], is supported by the results of enhanced micronutrient composition of our value-added product where sample $\mathrm{C}$ contain higher amounts of vitamin $\mathrm{C}$ and $\mathrm{Ca}$ compared to the control. In general, these results are in congruence with documented evidence of increased mineral and vitamin contents of ice creams fortified with different fruits such as Indian gooseberry, banana, guava, pear pulp, lemon and passion fruit [36] [37].

\subsection{Physicochemical Properties}

The physiochemical composition of the ice cream samples as presented in Table 3 range from. $4.47-6.48$ for $\mathrm{pH}$ as well as $0.028 \%-0.07 \%$ and $18.67 \%-34.49 \%$ for TTA and TS respectively The $\mathrm{pH}$ of sample A was near neutral which was in agreement with previous findings [38] while those of the formulated ice cream samples had lower $\mathrm{pH}$ values similar to earlier findings, which suggest that slight lactic acid fermentation takes place during production of kunu-zaki [39]. Since

Table 3. Physico-chemical parameters of the ice cream samples.

\begin{tabular}{cccc}
\hline & $\mathrm{pH}$ & TTA (\%) & TS (\%) \\
\hline A & $6.485 \pm 0.007^{\mathrm{d}}$ & $0.077 \pm 0.007^{\mathrm{c}}$ & $34.490 \pm 0.353^{\mathrm{d}}$ \\
B & $4.475 \pm 0.007^{\mathrm{a}}$ & $0.028 \pm 0.001^{\mathrm{a}}$ & $26.250 \pm 0.042^{\mathrm{c}}$ \\
C & $4.975 \pm 0.021^{\mathrm{c}}$ & $0.044 \pm 0.002^{\mathrm{b}}$ & $21.565 \pm 0.035^{\mathrm{b}}$ \\
D & $4.740 \pm 0.014^{\mathrm{b}}$ & $0.028 \pm 0.001^{\mathrm{a}}$ & $18.670 \pm 0.282^{\mathrm{a}}$ \\
p-value & 0.001 & 0.001 & 0.001 \\
\hline
\end{tabular}

Values are Mean \pm Standard deviation for two independent determinations. Values with different superscript down the column differ significantly at $\mathrm{p}<0.05$ (Duncan Multiple range test). 
lower $\mathrm{pH}$ in foods helps to reduce the activity of spoilage microorganism it implies that ice cream samples B, C and D may have higher shelf stability than sample A. The percentage total titrable acidity (TTA) for the formulated ice cream samples followed the expected trend of the higher the $\mathrm{pH}$ the lower the total acidity as seen in samples B, C, D and vice versa as reported by others [40]. Generally, the results of analysis of physicochemical properties, particularly $\mathrm{pH}$ and total solids are in consonance with other previous reports, and more recently with those obtained in a study that analysed characteristics of roselle plant extract-fortified ice creams [41].

\subsection{Amino Acid Profile}

Total amino acid content of the formulated and control ice cream samples as presented in Table 4 range from 26.54 - 41.28. While the values of samples B and C are similar to the control sample A, sample D recorded the highest amount of

Table 4. Amino acid content of the ice cream samples.

\begin{tabular}{|c|c|c|c|c|}
\hline Amino acid & A & B & $\mathrm{C}$ & $\mathrm{D}$ \\
\hline Leucine & $3.505 \pm 0.007^{c}$ & $2.505 \pm 0.007^{\mathrm{b}}$ & $0.870 \pm 0.000^{\mathrm{a}}$ & $4.960 \pm 0.000^{\mathrm{d}}$ \\
\hline Lysine & $2.065 \pm 0.007^{c}$ & $1.585 \pm 0.007^{\mathrm{b}}$ & $0.640 \pm 0.000^{\mathrm{a}}$ & $2.405 \pm 0.007^{\mathrm{d}}$ \\
\hline Isoleucine & $2.220 \pm 0.014^{c}$ & $0.980 \pm 0.000^{\mathrm{b}}$ & $0.385 \pm 0.007^{\mathrm{a}}$ & $2.380 \pm 0.000^{\mathrm{d}}$ \\
\hline Phenylalanine & $1.050 \pm 0.014^{\mathrm{b}}$ & $1.055 \pm 0.007^{\mathrm{b}}$ & $0.705 \pm 0.007^{\mathrm{a}}$ & $1.850 \pm 0.000^{\mathrm{d}}$ \\
\hline Tryptophan & $0.460 \pm 0.014^{c}$ & $0.420 \pm 0.000^{\mathrm{b}}$ & $0.305 \pm 0.007^{\mathrm{a}}$ & $0.675 \pm 0.007^{\mathrm{d}}$ \\
\hline Valine & $0.820 \pm 0.000^{c}$ & $0.645 \pm 0.007^{\mathrm{b}}$ & $0.520 \pm 0.014^{\mathrm{a}}$ & $2.340 \pm 0.000^{\mathrm{d}}$ \\
\hline Methionine & $0.745 \pm 0.007^{\mathrm{b}}$ & $0.810 \pm 0.014^{\mathrm{c}}$ & $0.550 \pm 0.014^{\mathrm{a}}$ & $1.145 \pm 0.007^{\mathrm{d}}$ \\
\hline Histidine & $0.950 \pm 0.014^{\mathrm{b}}$ & $1.080 \pm 0.014^{\mathrm{c}}$ & $0.380 \pm 0.000^{\mathrm{a}}$ & $1.150 \pm 0.000^{\mathrm{d}}$ \\
\hline Threonine & $1.655 \pm 0.007^{\mathrm{c}}$ & $0.990 \pm 0.014^{\mathrm{b}}$ & $0.440 \pm 0.000^{\mathrm{a}}$ & $2.355 \pm 0.007^{\mathrm{d}}$ \\
\hline Cysteine & $0.305 \pm 0.007^{\mathrm{a}}$ & $0.480 \pm 0.000^{c}$ & $0.725 \pm 0.007^{\mathrm{d}}$ & $0.355 \pm 0.007^{\mathrm{b}}$ \\
\hline Alanine & $0.990 \pm 0.000^{c}$ & $0.835 \pm 0.007^{\mathrm{b}}$ & $0.760 \pm 0.000^{\mathrm{a}}$ & $2.045 \pm 0.007^{\mathrm{d}}$ \\
\hline Glutamic acid & $3.165 \pm 0.021^{\mathrm{a}}$ & $4.345 \pm 0.007^{\mathrm{c}}$ & $3.635 \pm 0.007^{\mathrm{b}}$ & $5.135 \pm 0.007^{\mathrm{d}}$ \\
\hline Glycine & $0.950 \pm 0.000^{\mathrm{a}}$ & $2.085 \pm 0.007^{\mathrm{d}}$ & $1.005 \pm 0.007^{\mathrm{b}}$ & $1.045 \pm 0.007^{\mathrm{c}}$ \\
\hline Serine & $1.215 \pm 0.007^{\mathrm{b}}$ & $1.560 \pm 0.014^{\mathrm{c}}$ & $0.860 \pm 0.000^{\mathrm{a}}$ & $2.080 \pm 0.000^{\mathrm{d}}$ \\
\hline Aspartic acid & $2.475 \pm 0.007^{\mathrm{b}}$ & $4.275 \pm 0.007^{\mathrm{d}}$ & $1.355 \pm 0.007^{\mathrm{a}}$ & $3.435 \pm 0.007^{\mathrm{c}}$ \\
\hline Proline & $1.010 \pm 0.000^{\mathrm{b}}$ & $1.005 \pm 0.007^{\mathrm{b}}$ & $0.405 \pm 0.007^{\mathrm{a}}$ & $2.340 \pm 0.000^{c}$ \\
\hline Arginine & $2.580 \pm 0.000^{c}$ & $1.200 \pm 0.000^{\mathrm{a}}$ & $2.410 \pm 0.000^{\mathrm{b}}$ & $3.705 \pm 0.007^{\mathrm{d}}$ \\
\hline Tyrosine & $0.515 \pm 0.007^{\mathrm{b}}$ & $0.685 \pm 0.007^{c}$ & $0.345 \pm 0.007^{\mathrm{a}}$ & $1.885 \pm 0.007^{\mathrm{d}}$ \\
\hline Leucine & $3.505 \pm 0.007^{\mathrm{c}}$ & $2.505 \pm 0.007^{\mathrm{b}}$ & $0.870 \pm 0.000^{\mathrm{a}}$ & $4.960 \pm 0.000^{\mathrm{d}}$ \\
\hline TEAA & 13.47 & 10.07 & 4.795 & 19.26 \\
\hline TNEAA & 13.205 & 16.47 & 11.5 & 22.025 \\
\hline TAA & 26.675 & 26.54 & 26.295 & 41.285 \\
\hline
\end{tabular}

Values are Mean for two independent determinations. Values with same superscript down are not statistically significant (Duncan Multiple range test) at $\mathrm{p}>0.05$. 
Table 5. Sensory attributes of the ice cream samples.

\begin{tabular}{cccccccc}
\hline & Colour & Flavour & Taste & Mouth feel & Consistency & After taste & Overall acceptability \\
\hline A & $7.90 \pm 1.00^{\mathrm{a}}$ & $8.00 \pm 0.71^{\mathrm{bc}}$ & $7.55 \pm 1.34^{\mathrm{b}}$ & $7.67 \pm 0.69^{\mathrm{b}}$ & $8.00 \pm 0.55^{\mathrm{c}}$ & $7.70 \pm 0.55^{\mathrm{b}}$ & $8.00 \pm 0.55^{\mathrm{c}}$ \\
B & $7.89 \pm 0.84^{\mathrm{a}}$ & $8.20 \pm 0.70^{\mathrm{c}}$ & $7.53 \pm 0.89^{\mathrm{b}}$ & $7.40 \pm 0.71^{\mathrm{b}}$ & $7.98 \pm 0.89^{\mathrm{b}}$ & $7.75 \pm 0.55^{\mathrm{bc}}$ & $7.95 \pm 0.71^{\mathrm{b}}$ \\
C & $7.93 \pm 0.71^{\mathrm{a}}$ & $7.90 \pm 0.55^{\mathrm{b}}$ & $7.12 \pm 1.14^{\mathrm{a}}$ & $7.23 \pm 1.00^{\mathrm{a}}$ & $7.95 \pm 0.84^{\mathrm{b}}$ & $7.67 \pm 0.45^{\mathrm{b}}$ & $7.90 \pm 1.22^{\mathrm{b}}$ \\
D & $7.99 \pm 0.48^{\mathrm{a}}$ & $6.90 \pm 0.54^{\mathrm{a}}$ & $7.00 \pm 0.55^{\mathrm{a}}$ & $7.12 \pm 0.71^{\mathrm{a}}$ & $7.50 \pm 1.23^{\mathrm{a}}$ & $6.90 \pm 1.20^{\mathrm{a}}$ & $7.00 \pm 0.84^{\mathrm{a}}$ \\
ANOVA & 0.043 & 0.043 & 0.280 & 0.019 & 0.006 & 0.003 & 0.006 \\
\hline
\end{tabular}

Data are presented as mean \pm standard deviation. Values with different superscript down the column are statistically significant (Duncan Multiple range test) at $\mathrm{p}<0.05$.

total amino acid profile. More importantly, the samples contained reasonable amounts of essential amino acids content with sample D being consistently significantly different $(\mathrm{p}<0.05)$ compared with sample A, which further confirms the result of protein content from proximate analysis. The result of high amino acid content agrees with that reported from analysis of nutrient composition of avocados, which surmised its health potential [42]. The amounts of essential amino acid such as isoleucine, leucine, lysine and valine, which have a huge role in muscle growth and function was higher in the formulated ice cream sample $\mathrm{D}$, suggesting a good driver for these essential nutrients and improvement on nutritive value of ice cream.

\subsection{Sensory Attributes of the Ice Cream Samples}

The sensory attributes of the formulated ice cream samples as well as the control, which range from $6.90-8.20$ on a 9-hedonic scale is as presented in Table 5. The results show that all samples including the control have similar rating by the panelists in terms of colour, flavor, taste, mouth feel, consistency, after taste and overall acceptability as the values only vary slightly, in similar fashion to documented reports [32] [43]. However, the control sample had marginally higher rate values of overall acceptability. This may not be unconnected with the inclusion of additives such as colouring agents and sweeteners, which may have positively impacted on the general sensory attributes.

\section{Conclusion}

Results from this study show that value addition of "kunu-zaki" through formulation of novel ice cream products fortified with fruit pulp contains essential nutrients capable of supplementing the daily requirement. However, there is a need to improve the percentage of soymilk to make up for the low protein content of kunu-zaki, which is the focus of our future work.

\section{Acknowledgements}

The authors appreciate the director and management of Center for Food Technology and Research (CEFTER), Benue State University for supporting the financial cost of experimental work. 


\section{Conflicts of Interest}

The authors declare no conflict of interest.

\section{References}

[1] Hemali, H.P. and Bijal, K.A. (2015) Formulation and Standardization of Different Milk Ice-Cream Fortified with Pink Guava Pulp. International Journal of Dairy Science, 10, 219-227. https://doi.org/10.3923/ijds.2015.219.227

[2] McCann, S.E., Hays, J., Baumgart, C.W., Weiss, E.H., Yao, S. and Ambrose, C.B. (2017) Usual Consumption of Specific Dairy Foods Is Associated with Breast Cancer in the Roswell Park Cancer Institute Data and BioRepository. Current Developments in Nutrition, 1, e000422. https://doi.org/10.3945/cdn.117.000422

[3] Kumari, J. and Dubey, R.P. (2016) Development of Nutritious Ice-Creams from Soymilk and Pumpkin Seed Milk and Evaluation of Their Acceptability. Journal of Food Resource Science, 7, 96-100. https://doi.org/10.15740/HAS/FSRJ/7.1/96-100

[4] Umelo, M.C., Uzoukwu, A.E., Odimegwu, E.N., Agunwah, I.M., Njoku, N.E. and Alagbaoso, S.O. (2014) Proximate, Physiochemical and Sensory Evaluation of Ice Cream from Blends of Cow Milk and Tigernuts (Cyperusesculentus) Milk. International Journal of Scientific Research and Innovative Technology, 1, 63-76.

[5] Messina, M.J. (1999) Legumes and Soybeans: Overview of Their Nutritional Profiles and Health Effects. American Journal of Clinical Nutrition, 70, 439S-450S. https://doi.org/10.1093/ajcn/70.3.439s

[6] Gaffa, T., Jideani, I.A. and Nkama, I. (2002) Traditional Production, Consumption and Storage of Kunu: A Non-Alcoholic Cereal Beverage. Plant Food for Human $\mathrm{Nu}$ trition, 57, 73-81. https://doi.org/10.1023/A:1013129307086

[7] Amusa, N.A. and Ashaye, O.A. (2009) Effect of Processing on Nutritional, Microbiological and Sensory Properties of Kunun-Zaki (A Sorghum Based Non-Alcoholic Beverage) Widely Consumed in Nigeria. Pakistan Journal of Nutrition, 8, 288-292. https://doi.org/10.3923/pjn.2009.288.292

[8] Ogo, A.O., Kparev, M., Amali, E.O.O. and Obochi, G.O. (2018) Optimising Soymilk Protein Nutriture through Selection of Appropriate Processing Technique. Nigerian Journal of Pure and Applied Sciences, 31, 10-21. http://napas.org.ng/index.php/napas/article/view/64

[9] Slavin, J.L. and Lloyd, B. (2012) Health Benefits of Fruits and Vegetables. Advance Nutrition, 3, 506-516. https://doi.org/10.3945/an.112.002154

[10] Lorenza, R. (2014) The Nutrition and Health Situation of Nigeria. Nutrition and Health Survey Using SMART Methods, February-May, 2014. https://www.nigerianstat.gov.ng/download/404

[11] Demelash, H. and Dadi, A.F. (2019) Burden and Determinants of Malnutrition among Pregnant Women in Africa: A Systematic Review and Meta-Analysis. PLoS $O N E, 14$, e0221712. https://doi.org/10.1371/journal.pone.0221712

[12] Konstantas, A., Stamford, L. and Azapagic, A. (2019) Environmental Impacts of Ice Cream. Journal of Cleaner Production, 209, 259-272. https://doi.org/10.1016/j.jclepro.2018.10.237

[13] Gaffa, T., Jideani, I.A. and Nkama, I. (2002) Soybean Seed in Kunu Zaki Beverage Production. Pakistan Journal of Biological Sciences, 5, 970-973. https://doi.org/10.3923/pjbs.2002.970.973

[14] Bear, A.C. (1993) Ice Cream Making. University of Wisconsin. Agricultural Experiment Station: Bulletin, 4, 38-39. 
[15] AOAC (2007) Association of Official Analytical Chemist. Fifteenth Edition, Official Methods of Analysis, Washington DC.

[16] AOAC (2015) Association of Official Analytical Chemist. Seventeenth Edition, Washington DC.

[17] Benitez, L.V. (1989) Amino Acid and Fatty Acid Profiles in Aquaculture Nutrition Studies. p. 23-35. In: De Silva, S.S., Ed., Fish Nutrition Research in Asia. Proceedings of the Third Asian Fish Nutrition Network Meeting, Society Special Publication No. 4, Asian Fisheries Society, Manila, 166 p. http://hdl.handle.net/10862/312

[18] AOAC (2005) Association of Official Analytical Chemist. Eighteen Edition, Washington DC.

[19] Iwe, M.O. (2007) Current Trend in Sensory Evaluation of Foods. Rojoint Communication Services Limited, Enugu, 136-138.

[20] Chansathirapanich, W., Ngamchuachit, P. and Tansawat, R. (2016) Effect of Fat Content on Characteristics of Ice Cream Fortified with Calcium and Vitamin D. Thai Journal of Pharmaceutical Sciences, 40, 132-138.

http://www.tjps.pharm.chula.ac.th/ojs/index.php/tjps/article/view/173

[21] Gita, B., Poornima, V.A. and Sheel, S. (2012) Development of Ice Creams from Soybean Milk \& Watermelon Seeds Milk and Evaluation of Their Acceptability and Nourishing Potential. Journal of Advances in Applied Science Research, 3, 371-376. https://doi.org/10.5958/j.2231-1750.3.1.001

[22] Kasa, T. and Yohanis, F.G. (2017) Chemical Composition and Nutritional Effect of Pineapple, Mango, Banana, Avocado and Orange: A Review Article. Chemical and Process Engineering Research, 54, 1-6. http://www/Downloads/39079-42196-1-PB\%20(3)pdf

[23] Deosarkar, K.S. and Khedkar, C. (2016) Ice Cream: Composition and Health Effects. In: Encyclopedia of Food and Health, Elsevier, London, 385-390. https://doi.org/10.1016/B978-0-12-384947-2.00385-8

[24] Soares, H.F. and Ito, M.K. (2002) The Monounsaturated Fatty Acid from Avocado in the Control of Dyslipidemia. Revista Ciências Médicas, 9, 47-51. http://www.scielo.br/pdf/cr/v46n4/1678-4596-cr-46-04-00747.pdf

[25] Adebayo, G.B., Otunola, G.A. and Ajao, T.A. (2010) Physicochemical, Microbiological and Sensory Characteristics of Kunun Prepared from Millet, Maize and Guinea Corn and Stored at Selected Temperatures. Advanced Journal of Food Science and Technology, 2, 41-46.

https://www.airitilibrary.com/Publication/alDetailedMesh?docid=20424876-201001 $\underline{-201009060052-201009060052-41-46}$

[26] Ruiz-Canizales, J., Domínguez-Avila, J.A., Wall-Medrano, A., Ayala-Zavala, J.F., González-Córdova, A.F., Vallejo-Córdoba, B., Salazar-López, N.J. and González-Aguilar, G.A. (2019) Fiber and Phenolic Compounds Contribution to the Hepatoprotective Effects of Mango Diets in Rats Fed High Cholesterol/Sodium Cholate. Phytotherapy Research, 33, 2996-3007. https://doi.org/10.1002/ptr.6479

[27] Corradini, S.A.S., Madrona, G.S., Visentainer, J.V., Bonafe, E.G., Carvalho, C.B., Roche, P.M. and Padro, I.N. (2014) Sensorial and Fatty Acid Profile of Ice Cream Manufactured with Milk of Crossbred Cows Fed Palm Oil and Coconut Fat. Journal of Dairy Science, 97, 6745-6753. https://doi.org/10.3168/jds.2014-8290

[28] Okoye, E.C., Onyekwelu, C.N. and Nghowu, C.A. (2018) Development, Quality Evaluation and Acceptability of Ice Cream from Cow Milk, Tigernut and African Yam Bean Seed Milk. Asian Food Science Journal, 3, 1-8. 
https://doi.org/10.9734/AFSJ/2018/42663

[29] Dongxiao, S.L., Edmonds, S.S. and Wibisono, R. (2013) Producing Ice Cream Using a Substantial Amount of Juice from Kiwifruit with Green, Gold or Red Flesh. Food Research International, 50, 647-656. https://doi.org/10.1016/j.foodres.2011.05.030

[30] Giuseppina, B. (2012) Oxidative Stress and Lipid Peroxidation Products in Cancer Progression and Therapy. International Scholarly Research Notices, 2012, Article ID: 137289. https://doi.org/10.5402/2012/137289

[31] Shahmihammadi, M., Javadi, M. and Nassiri-Asln, M. (2016) An Overview on the Effects of Sodium Benzoate as a Preservative in Food Products. Biotechnology and Health Sciences. (In Press) https://doi.org/10.17795/bhs-35084

[32] Salama, H.H., El-Sayed, S.M. and Abdalla, A.M. (2017) Enhancing the Nutritive Values of Ice Milk Based on Dry Leaves and Oil of Moringa oleifera. American Journal of Food Technology, 12, 86-95. https://doi.org/10.3923/ajft.2017.86.95

[33] Van der Hee, R.M., Miret, S., Slettenaar, M., Duchateau, G.S., Rietveld, A.G., Wilkinson, J.E. and Fairweather-Tait, S.J. (2009) Calcium Absorption from Fortified Ice-Cream Formulations Compared with Calcium Absorption from Milk. Journal of the American Dietetic Association, 109, 830-835. https://doi.org/10.1016/j.jada.2009.02.017

[34] Abuajah, C.I., Ogbonna, A.C. and Osuji, C.M. (2015) Functional Components and Medicinal Properties of Food: A Review. Journal of Food Science and Technology, 52, 2522-2529. https://doi.org/10.1007/s13197-014-1396-5

[35] El-Samahy, S.K., Youssef, K.M. and Moussa, T.E. (2009) Producing Ice Cream with Concentrated Cactus Pear Pulp: A Preliminary Study. Journal of the Professional Association for Cactus Development, 11, 1-12. https://www.researchgate.net/publication/255621651

[36] Wangcharoen, W. (2011) Development of Job's Tears Ice Cream Recipes with Carrot Juice and Pumpkin Paste. Maejo International Journal of Science and Technology, 5, 390-400. https://www.researchgate.net/publication/263504109

[37] Rajpreet, K.G. and Bajwa, U. (2015) Enhancing the Functional Properties and Nutritional Quality of Ice Cream with Processed Amla (Indian Gooseberry). Journal of Food Science and Technology, 52, 7861-7871. https://doi.org/10.1007/s13197-015-1877-1

[38] Mortensen, M. (2017) Classification of Ice Cream and Related Frozen Products. Bulletin, 10, Article No. 1. https://lib.dr.iastate.edu/bulletin/vol10/iss123/1/

[39] Adegoke, G.O., Odeyemi, A.O., Hussien, O. and Ikheorah, J. (2007) Control of Ochratoxin A (OTA) in Kunu Zaki (A Non-Alcoholic Beverage) Using Daniellin ${ }^{\mathrm{TM}}$. African Journal of Agricultural Resources, 2, 200-202. https://www.researchgate.net/publication/297928755

[40] Kanwal, T.A. and Bushra, M. (2004) Comparative Analysis of Quality of Milk Collected from Buffalo, Cow, Goat and Sheep of Rawalpindi/Islamabad Region in $\mathrm{Pa}$ kistan. Asian Journal of Plant Sciences, 3, 300-305. https://doi.org/10.3923/ajps.2004.300.305

[41] Singo, T.M. and Beswa, D. (2019) Effect of Roselle Extracts on the Selected Quality Characteristics of Ice Cream. International Journal of Food Properties, 22, 42-53. https://doi.org/10.1080/10942912.2019.1567535

[42] Dreher, M.L. and Davenport, A.J. (2013) Hass Avocado Composition and Potential Health Effects. Critical Reviews in Food Science and Nutrition, 53, 738-750. https://doi.org/10.1080/10408398.2011.556759 
[43] Ndulaka, J.C., Obasi, N.E. and Omeire, G.C. (2014) Production and Evaluation of Reconstitutable Kunu-Zaki. Nigerian Food Journal, 32, 66-72.

https://doi.org/10.1016/S0189-7241(15)30119-3 